\title{
25. 沿道大気噮境におけるフロースルー遮音壁の特性に関する研究
}

\author{
一数值モデルでの検討一
}

Study on the effect of porous fences on air quality near roadway

-Evaluation by numerical calculation-

東海林孝幸*、北田敏廣*

Takayuki TOKAIRIN*, Toshihiro KITADA*

ABSTRACT ; Flow and pollutant concentration around a double-decked road were investigated using a two-dimensional numerical model. In this study, two types of fence (solid fence and porous one) that were installed at the ground level were considered. For the porous fences, porosity was varied as $0,20,40,50$, and $60 \%$ in the simulation. By using the results, we evaluated the effects of porous fences on air quality near road. Obtained results showed that (1) flow pattern in leeward of fence was dramatically changed around $40 \%$ porosity, (2) porous fences did not decrease concentration near the road when emission source exists only at the ground level, and (3) in contrast, when emission sources were set at both elevated and ground level, the fences with $60 \%$ porosity was effective to ease air pollution enhanced by the solid fences.

KEYWORDS ; Roadside environment, Porous fence, Air pollution, Numerical simulation

\section{1.はじめに}

大都市域中心での交通量の多さは恒常的な渋滞を生み、排ガスの拡散、騒音など沿道環境に与える影響は大きい。 その軽減のためにさまざまな対策が施されているが筆者らは、そのような対策のひとつ、道路端に設置してある遮 音壁に注目し、大気拡散の視点から遮音壁の存在が沿道大気環境に与える影響について数值シミュレーションを通 じ検討してきた。その結果、2階建て道路の場合、1 階部分の遮音壁の存在が道路風下の風速を弱め、沿道付近の 濃度を高める作用があること、一方逆に地上に排出源がある場合でも、2 階道路部の遮音壁の場合は地上付近の濃 度を軽減する可能性があることを示した 1)2。しかしながら、遮音壁はそもそも交通騒音を軽減する目的で設置され たものであり、大気污染軽減のためといってそれを撤去することはできない。今後、騒音、大気污染双方の沿道への 負荷を考える場合、どのような形態の遮音壁を用いればよいかの検討が必要である。本研究では大気拡散の観点か ら通気性のある道路遮音壁を仮定し遮音壁のポロシティと風速場、濃度場の関係を数值モデルにより検討した。

\section{2. 計算方法}

道路構造物の存在によって影響を受ける流れ場および拡散場は、標準 $\mathrm{k}-\varepsilon$ モデルにより計算した。また、流体 が通り抜けられる遮音壁を考慮するために遮音壁を多孔質体（Porous Media）として扱い、基礎方程式中にポロシ ティなどのパラメーターを与えることによって計算した。計算は空間 2 次元の定常状態を想定し、コードは CFX4 (AEA Technology，1997) 光使用した。Porous Media を考慮した方程式系を以下に示す。

\section{1 基礎方程式系}

連続の式 : $\quad \nabla \cdot(\rho \mathbb{K} \cdot \vec{U})=0$

$$
\text { 運動方程式 : } \quad \nabla \cdot(\rho(\mathbb{K} \cdot \vec{U}) \otimes \vec{U})-\nabla \cdot\left(\mu \mathbb{K} \cdot\left(\nabla \vec{U}+(\nabla \vec{U})^{T}\right)\right)=\vec{B}-\nabla p
$$

ここに、 $(\vec{U} \otimes \vec{U})_{i j}=U_{i} U_{j}$ である。

$$
\text { 污染物質の拡散方程式 : } \quad \nabla \cdot(\rho(\mathbb{K} \cdot \vec{U}) \Phi)-\nabla \cdot(\Gamma \mathbb{K} \cdot \nabla \Phi)=\gamma S
$$

ここで、 $\gamma 、 \mathbb{K}$ はそれぞれ Volume porosity（以下、ポロシティ）、Area porosity tensor と呼ばれる量であり物 体中に流体が占めることのできる割合、物体表面のポロシティ分布の偏りを示している。本研究では $\mathbb{K}$ は単位行 列と仮定した。 $\gamma$ にいては第 $3,4,5$ 章で示すよううに実験条件として定められた值（3 章）ないし、パラメー

*豊橋技術科学大学エコロジー工学系 Department of Ecological Engineering, Toyohashi University of Technology, 1-1 Hibarigaoka,Tempaku-cho,Toyohashi 441-8580,Japan 
タとして変化させる值（4,5章）とした。また、式(2)の右辺 $\vec{B}\left[\mathrm{~N} / \mathrm{m}^{3}\right]$ は流体が多孔質体中を通過するときの抵 抗を表す体積力であり、

$$
\vec{B}=-\gamma\left(R_{c}+R_{f}|\vec{U}|\right) \cdot \vec{U}
$$

で与えられる(例えば AEA Technology $\left.(1997)^{3)}\right)$ 。こで $R_{c}, R_{f}$ はそれぞれ Resistance constant $\left[\mathrm{kg} / \mathrm{m}^{3}\right]$ 、 Resistance speed factor $\left[\mathrm{kg} / \mathrm{m}^{4}\right]$ と呼ばれる量であり、ユーザーが值を指定する。本研究では $\mathrm{R}_{\mathrm{f}}$ について Packwood4)によって求められた式

$$
R_{f}=\frac{\rho C_{D}}{2 L}
$$

を使用した。ここで $\rho 、 \mathrm{~L}$ および $\mathrm{C}$ は はそれぞれ流体の密度 $\left(\mathrm{kg} / \mathrm{m}^{3}\right)$ 、遮音壁厚さ $(\mathrm{m}) 、$ 抵抗係数を表している。ま た、ポロシティと抵抗係数 $\mathrm{CD}$ の関係については多くの研究があるが、本研究では Richards and Robinson ${ }^{5)}$ が紹 介している式

$$
C_{D}=C_{D 0} \cdot\left(1-\gamma^{2}\right)
$$

を使用した。ここで $\mathrm{CD} 0$ は平板上の平行流中に垂直に設置してあるプレートの抵抗係数(=1.2 を与えた)である。

\section{2 境界条件}

境界条件は以下のように与えた。

(i ）流入面

速度：

$$
U_{\text {in }}(z)=\frac{u_{*}}{\kappa} \cdot \ln \left(\frac{z}{z_{0}}\right)
$$

ここに $\kappa$ はカルマン定数 $(=0.4) 、 \mathrm{u}_{*}$ は摩擦速度、 $\mathrm{z}_{0}$ は粗度長である。 $\mathrm{u}_{\star} 、 \mathrm{z}_{0}$ ともに実測風を基に決めた。た だし、この条件については第 $4 、 5$ 章の計算にのみ使用した。

乱れの運動エネルギー $\mathrm{k}$ : 入口速度の平均值として

$$
k_{\text {in }}=0.02 U_{\text {in }}^{2}
$$

乱れの消散速度 $\varepsilon$ ：

$$
\varepsilon_{i n}=\frac{C_{\mu}^{3 / 4} \cdot k^{3 / 2}}{\kappa z}
$$

（ii）地面および構造物表面

速度 : 地表面、構造物表面で速度は0の滑りなし壁とする。

$$
\mathrm{U}_{\mathrm{wall}}=\mathrm{W}_{\text {wall }}=0.0
$$

乱れの運動エネルギー $\mathrm{k}$ :

$$
k_{\text {wall }}=\frac{\tau}{\sqrt{C_{\mu}} \cdot \rho}
$$

ここに は壁面でのせん断応力である。

乱れの消散速度 $\varepsilon: \quad \quad \varepsilon_{\text {wall }}=\frac{C_{\mu}^{3 / 4} \cdot k^{3 / 2}}{\kappa z_{n}}$

ここに $\mathrm{z}$ は壁面から一番近いグリッドまでの距離を表す。

（iii）流出面および上端

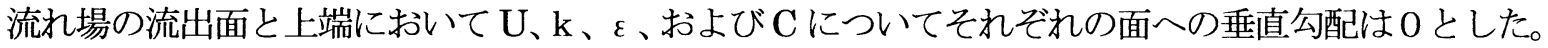

$$
\frac{\partial U_{i}}{\partial n}=0 \quad \frac{\partial k}{\partial n}=\frac{\partial \varepsilon}{\partial n}=\frac{\partial C}{\partial n}=0 \quad(\mathrm{i}=1,2)
$$

\section{3. モデルの検証}

数值計算で必要な抵抗に関するパラメータ $\left(\mathrm{R}_{f}\right)$ 值の妥当性を検討するため Lee and $\mathrm{Kim}^{6}$ )による実測データとの 比較を行った。彼らは平板上に垂直に置かれた高さ $40 \mathrm{~mm}$ 、厚さ $4 \mathrm{~mm}$ のプレートに穴を開けることによってポ

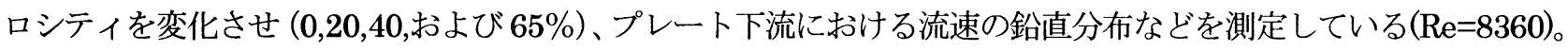
本研究においても同様の条件を設定し計算を行った。以下に実測值（図 1）と計算値（図 2）の比較を示寸。 


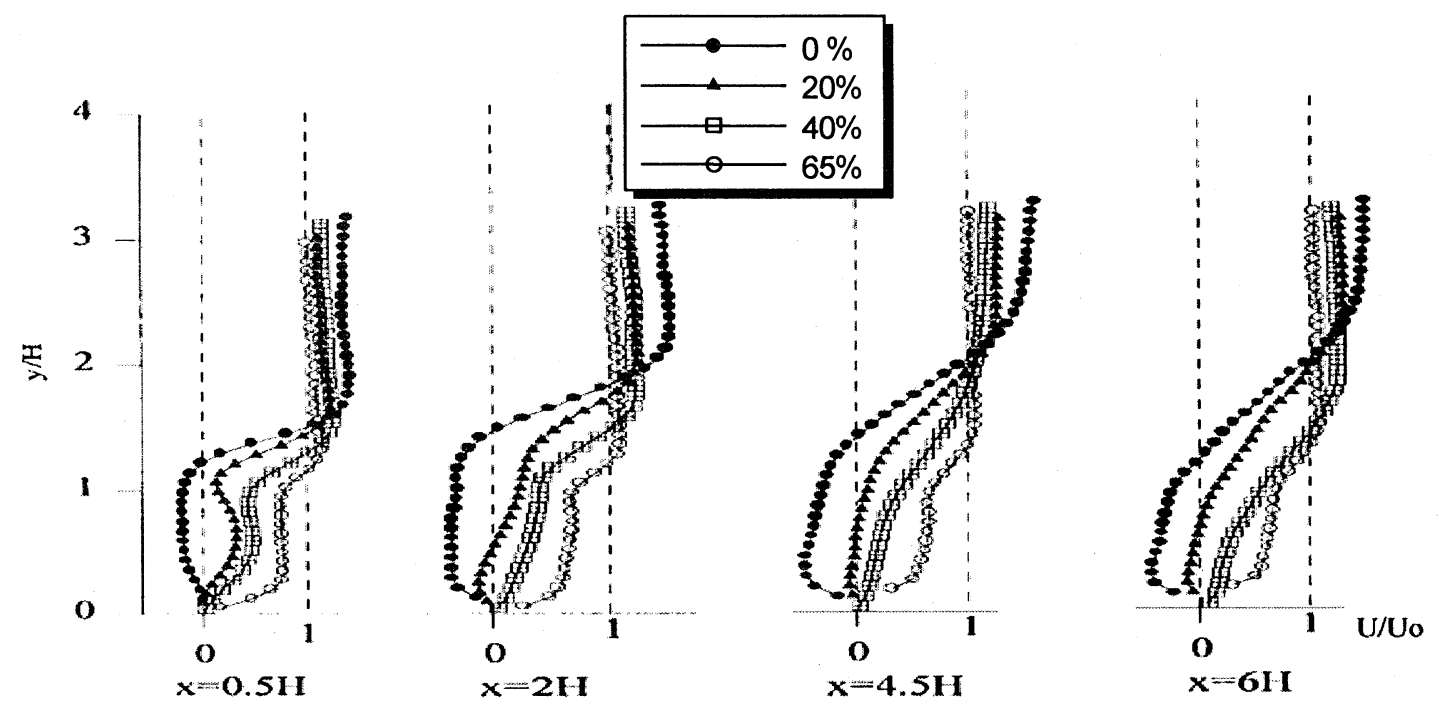

図 1 各ポロシティにおける水平方向流速の鉛直分布 : 実測值（図は Lee and Kim²)より抜粋）
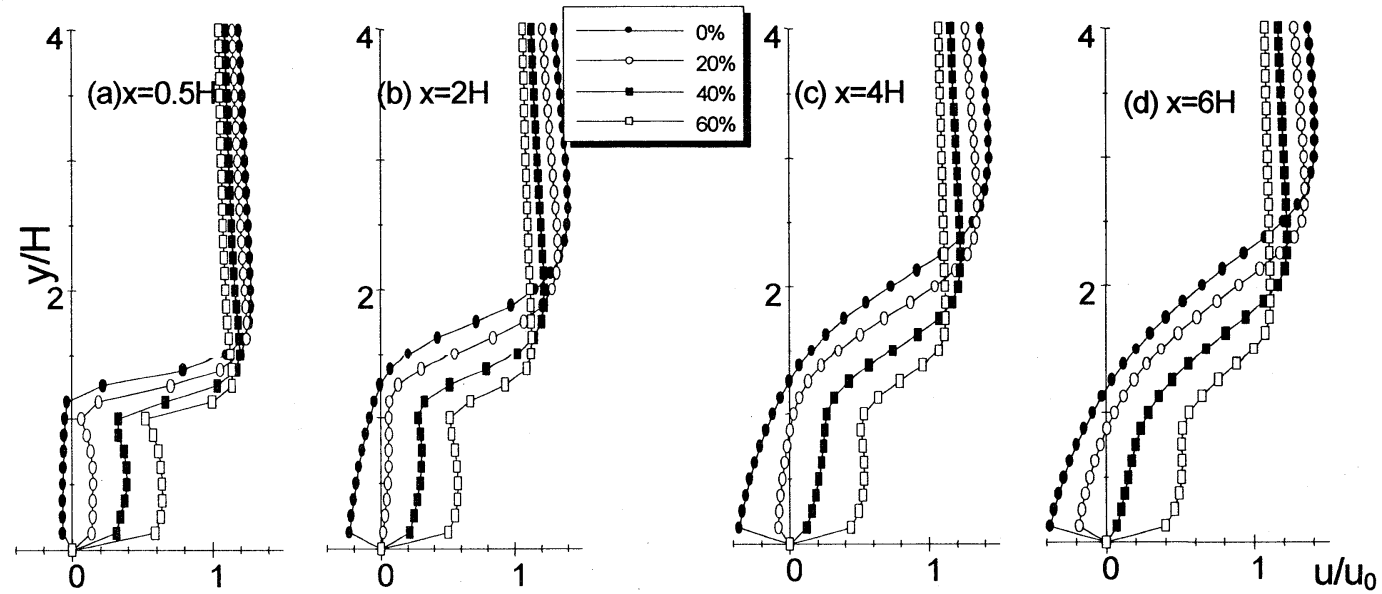

図 2 各ポロシティにおける水平方向流速の鉛直分布 : 計算值。Hはプレート高さ $(=40 \mathrm{~mm})$ である。変化させ たポロシティ $(\gamma)$ の值を\%で示している。

計算值では $\mathrm{x}=0.5 \mathrm{H}$ （図 2(a)）において遮音壁を通り抜けてきた流れの速度が実測值より若干小さく見積もられ ているが、風下距離が大きくなるに従い実測值と計算値はおおむね一致している。通気性のない遮音壁の場合、 $\mathrm{y}=1.2 \mathrm{H}$ より低い高さでは、風下全地点で $\mathrm{x}$ 方向風速が負值となり、遮音壁近傍に循環流が形成されていることを 表す。ポロシティ $20 \%$ の場合、 $\mathrm{x}=4 \mathrm{H}$ 付近に逆流域が発生し、循環流は遮音壁から離れた地点に形成されている ことを示す。さらに $40 \%$ 以上になると逆流域は形成されていない。

\section{4. 通気性遮音壁に伴う流れと拡散に関するシミュレーションケース}

第 2 章で述べた定式化を用いて、計算領域内に高架、平面道路併設タイプの道路構造を考え（図 3 )、風速の実 測值（国土技術政策総合研究所環境研究部 : 道路に直交する向き、遮音壁高さ $\left(4 \mathrm{~m} ）\right.$ における風速 $\mathrm{uh}_{\mathrm{h}}=1.3 \mathrm{~m} / \mathrm{s}$ ) を計算領域入り口に与え遮音壁のポロシティを変化させた場合の風速場、濃度場を計算した。本研究では(1)排出源 が平面道路上にのみ存在する場合（ケース 1)、(2)平面、高架両道路上に存在する場合（ケース 2) について計算 を行った。図 3 に道路構造の概略を示す。図中、平面、高架道路幅は $10 \mathrm{~m}$ 、遮音壁高さは $4 \mathrm{~m}$ 、厚さは $0.1 \mathrm{~m}$ とし た。

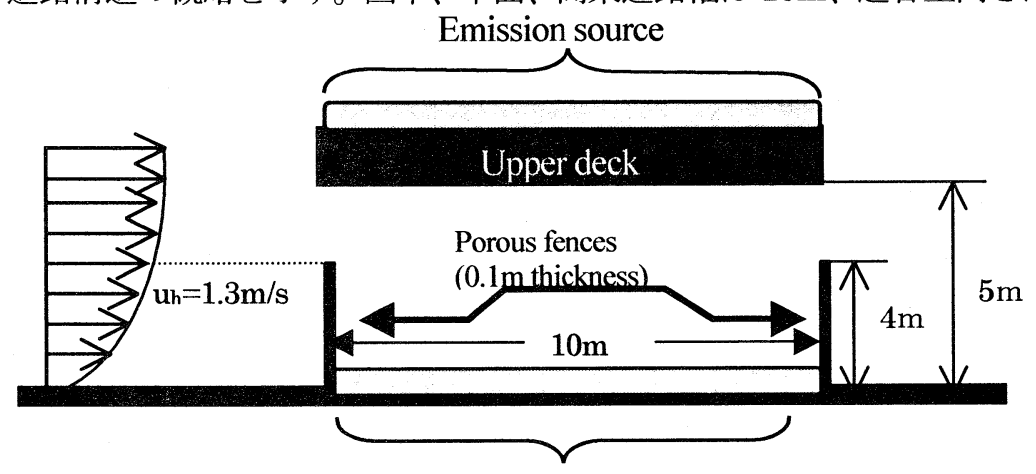

Emission source 
5. 通気性遮音壁に関する計算結果

本章では第 4 章のシミュレーションケースに示す現実に近い条件で通気性のあるフェンスが流れおよび拡散に 及ぼす効果を検討した。

\section{1 風速場の特性}

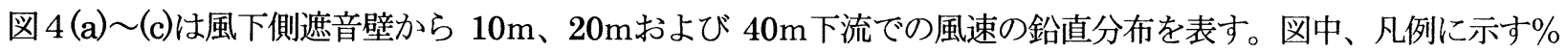
值はポロシティを表す。
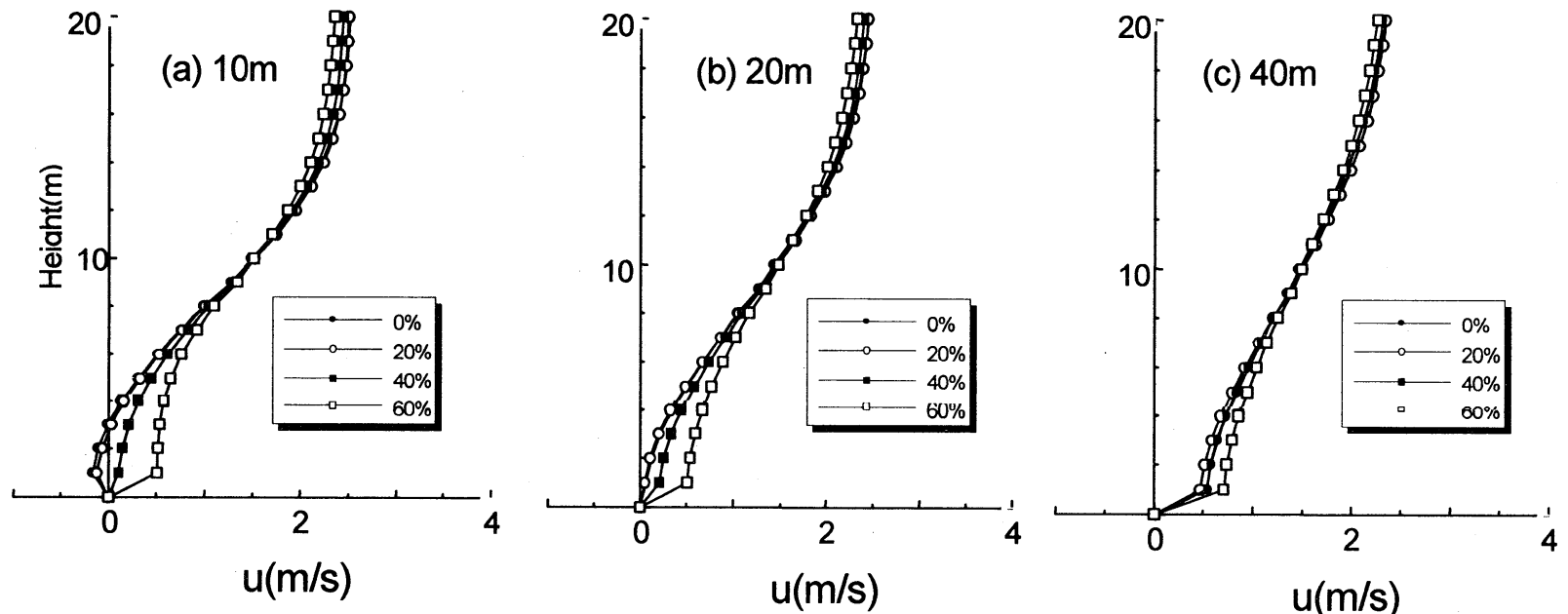

図4 ポロシティを変化させた場合の風速の鉛直分布の変化。風下距離 : (a) $10 \mathrm{~m},(\mathrm{~b}) 20 \mathrm{~m}$, (c) $40 \mathrm{~m}$

図よりポロシティが $40 \% 、 60 \%$ の場合、風下各地点において水平方向の風速は正值であり、渦の形成はない。 ポロシティが $0 \% 、 20 \%$ では遮音壁付近の下層に循環流が形成されている（図 $4(\mathrm{a})$ )。また風下 $20 \mathrm{~m}$ (フェンス高 さの 5 倍距離）を過ぎると、ポロシティ $20 \%$ と $40 \%$ の風速分布は急速に近くなる（図 4 (b)、(c))。このことは図 5 の流線図にも示されている。すなわち、フェンス高さの 5 倍距離 $(20 \mathrm{~m})$ 程度までにポロシティ $20 \%$ の場合の 渦構造も終わり、以後、上・下層の風向がそろって図 $5(\mathrm{a}),(\mathrm{b}),(\mathrm{c})$ の流れ場に定性的には差がなくなる。ただし、 図 4、5のいずれもが示唆するようにポロシティが $60 \%$ の場合には、それ以下に比べて下層の風速が大きく、風 下 $40 \mathrm{~m}$ の距離でも他のケースより $25 \%$ 程度の大きな風速を保つことが示されている。後に 5.3 で述べるように、 もしポロシティ $60 \%$ が許されるならば、このことが遮音壁設置による大気污染の悪化を軽減することにつながる 可能性がある。
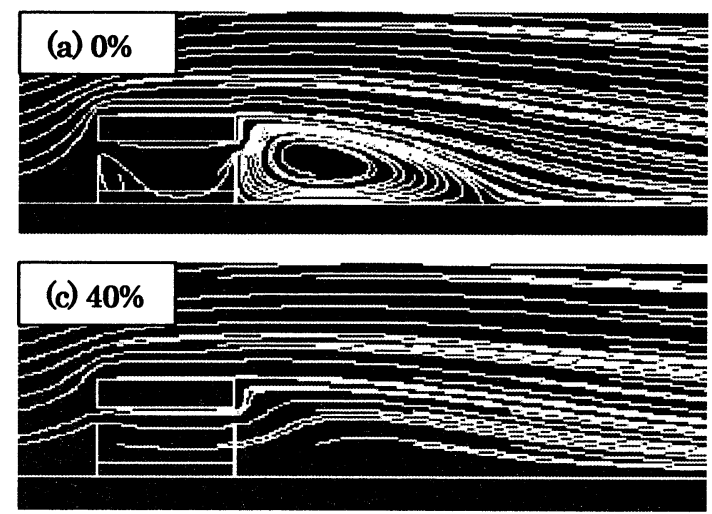
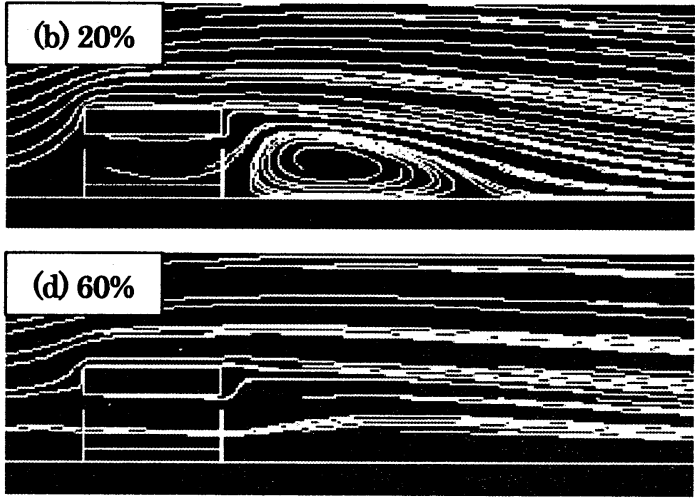

図 5 道路構造物周辺の流れ場（流線）

\section{2 濃度場（ケース $1:$ 平面道路上排出源）}

図 6(a)〜(c)は図 4 に対応する地点でのケース 1 の濃度鉛直分布を示す。ケース 1 では排出源が平面道路上にの み設定されている。 

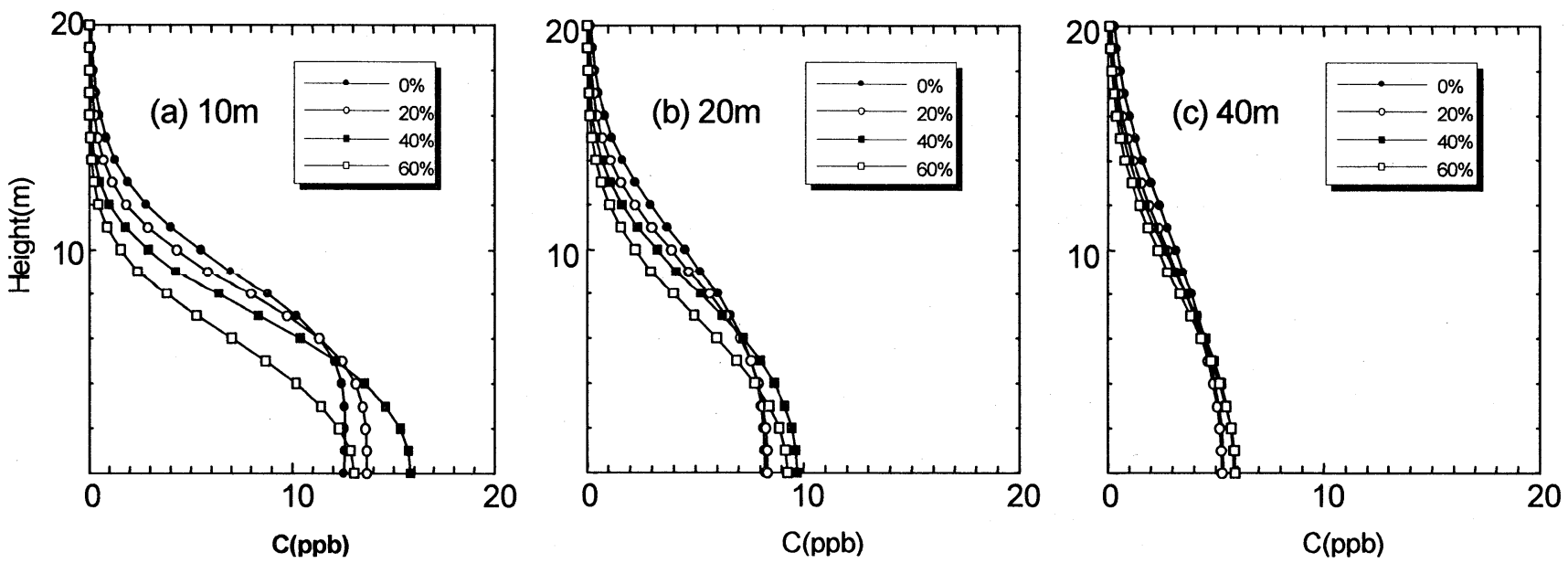

図 6 ポロシティを変化させた場合の濃度の鋁直分布（ケース 1 )。風下距離 : (a) $10 \mathrm{~m},(\mathrm{~b}) 20 \mathrm{~m}$, (c) $40 \mathrm{~m}$

図 6(a)，(b)，(c)の結果より、二階建て道路の二階部分に交通量がなく、上部デッキが一階道路部に対する屋根の 役割しか果たしていない場合には、一階部分の遮音壁にポロシティ $50 \%$ 程度の通気性を与えることはむしろ沿道 の下層濃度を高めることにしかならないと結論できる。この場合には通気性 $60 \%$ でも必ずしも良い結果を与えな い(図6(b))。先の筆者ら 2)の計算では、同じ設定で遮音壁なしが好ましい低濃度をもたらすことから、この状況 下では“遮音壁に中途半端な通気性を付与寸ることは沿道大気污染の軽減につながらない”といえる。遮音壁と上 部デッキの間隔からの吹き出しが污染物質の高さ方向への拡散を促して地表濃度を低減する効果が、弱い通気性付 与に伴う污染物質の水平移流効果より勝るものと判断できる (図 6(a),(b))。

\section{3 濃度場（ケース $2:$ 平面道路および高架道路上排出源）}

ケース 1 は二階建て道路の二階部分に交通を仮定しないという仮想的な場合である。現実にはむろん道路の目 的からみて二階道路にも排出源があると考えるのが普通である。ケース 2 はこの状況を代表する。図 7 (a)〜 (c)は 高架、平面道路に排出源を設定した場合の各地点における濃度鉛直分布を表す。
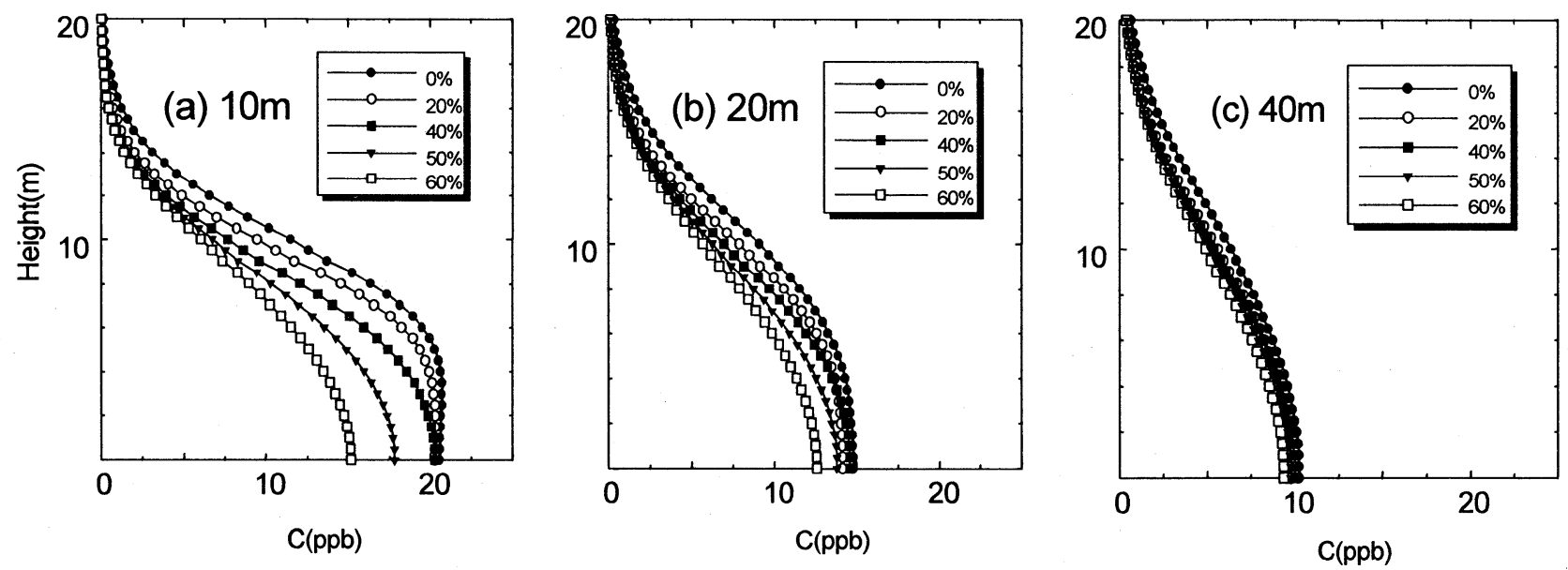

図 7 ポロシティを変化させた場合の濃度の鉛直分布（ケース 2)。風下距離 : (a) $10 \mathrm{~m}$, (b) $20 \mathrm{~m}$, (c) $40 \mathrm{~m}$

図よりケース 2 では遮音壁にポロシティ $60 \%$ の通気性を与える場合が、最も沿道近傍の大気污染の軽减につな がることが示されている (図 7(a)-10m，図 7(b)-20m)。他方、ポロシティ $40 \%$ までではまったく効果がなく、ま た $50 \%$ の場合、沿道 $10 \mathrm{~m}$ では効果があるが $20 \mathrm{~m}$ になるとほとんど濃度の軽減がない (図 $7(\mathrm{~b}))$ 。以上の結果に は、図 $5(\mathrm{a}),(\mathrm{b})(\mathrm{c})$ にみられる循環流の存在が大きく寄与している。すなわち、ポロシティが小さい場合、フェ ンス通過後の下層の水平風が小さく、上部の空気が地表付近まで引さ下ろされるが、これが二階部分で発生した污 染物質の地表高濃度への寄与につながっている。ポロシティ $60 \%$ では、この引き下ろし効果を妨げる程度に下層 の風速が大きくなることを意味する。

\section{6. 結論}

二階建て道路の平面部の遮音壁が沿道大気環境の悪化をもたらす可能性 $\left.{ }^{2}\right)$ から、遮音壁に部分的な通気性を持 たせることの効果を検討した。道路端に設置されている遮音壁は元来騒音対策のためのものであるが、遮音壁の通 
気性が周辺の風速場、濃度場をどのように変化させるのか数值計算により検討した。現時点で得られた知見をまと めると、渞路周讱の風速場の形熊については特にポロシティが $40 \%$ 前後を境に循環流の生成、消滅がおこり大き な違いを生じる（図 5）。このような風速場のもとで発生源が地上にのみ存在する場合（ケース 1）とより現実に 近い高架と平面両方に存在する場合（ケース 2) の拡散計算を行った。現実的なケース 2 ではポロシティが $60 \%$ で濃度が他より大きく減少した。これは前述のように循環流の生成がなく、二階部分での排出が地表濃度に影響し なかったことを示す。これらの結果を踏まえ今後、騒音・大気拡散双方を考慮したより良い遮音壁の形態、配置な どを検討する必要性があると考えられる。

\section{7. 参考文献}

1) T. Tokairin, T. Kitada: Numerical Investigation of the Effect of Road Structures on Ambient Air Quality -For their better design - , Proceedings of The $4^{\text {th }}$ seminar of JSPS-MOE Core University Program on Urban Environment, 34-42 (2002)

2) T. Tokairin, T. Kitada: Numerical Investigation of the Effect of Road Structures on Ambient Air Quality - For their better design -, Journal of Wind Engineering and Industrial Aerodynamics (submitted)

3) AEA Technology: CFX4-2 Solver manual, AEA Technology (1997)

4) A. R. Packwood: Flow through porous fences in thick boundary layers: comparisons between laboratory and numerical experiments, Journal of Wind Engineering and Industrial Aerodynamics, Vol. 88, 75-90 (2000)

5) P. J. Richards, M. Robinson: Wind loads on porous structures, Journal of Wind Engineering and Industrial Aerodynamics, Vol. 83, 455-465 (1999)

6) S. J. Lee, H. B. Kim: Laboratory measurements of velocity and turbulence field behind porous fences, Journal of Wind Engineering and Industrial Aerodynamics, Vol. 80, 311-326 (1999)

\section{謝辞}

本研究の遂行にあたり国土技術政策総合研究所環境研究部 松下雅行氏より、道路からのトレーサーガス 拡散の実測值など貴重なデータをご提供いただいた。ここに感謝の意を表します。 